\title{
DETECTION OF MENDELIAN AND GENOTYPE FREQUENCY OF GROWTH HORMONE GENE IN ONGOLE CROSSBRED CATTLE MATED BY THE ARTIFICIAL INSEMINATION TECHNIQUE
}

\author{
U. Paputungan ${ }^{1,2}$, L. Hakim ${ }^{3}$, G. Ciptadi ${ }^{3}$ and H.F.N. Lapian ${ }^{1}$ \\ ${ }^{1}$ Faculty of Animal Science, Sam Ratulangi University, Manado 95115 - Indonesia \\ ${ }^{2}$ Graduate School, Department of Animal Production, \\ Brawijaya University,Malang 65145 - Indonesia \\ ${ }^{3}$ Faculty of Animal Husbandry, Brawijaya University, Malang 65145 - Indonesia \\ Corresponding E-mail: umarfapet@yahoo.com
}

Received April 16, 2012; Accepted May 28, 2012

\begin{abstract}
ABSTRAK
Tujuan penelitian ini adalah menetapkan pewarisan gen hormon pertumbuhan (HP) melalui jenis Mendel dan menentukan frekuensi genotype HP pada sapi peranakan Ongole yang dikawinkan dengan teknik inseminasi buatan (IB). Sebanyak 76 sampel darah diambil dari induk Peranakan Ongole dan pejantan (G0), dan keturunannya (G1) di Desa Tumaratas sebagai Pusat Pelayanan IB provinsi Sulawesi Utara, Indonesia. Semua sampel darah diuji keberadaan lokus HP dengan memakai metode PCR-RFLP yang melibatkan restriksi enzyme Mspl pada 1,2\% gel agarosa. Data dianalisis dengan menggunakan fungsi program statistik pada Excel XP. Hasil menunjukkan bahwa lokus HP yang memakai alel restriksi enzim Mspl+ dan Mspl- dalam induk dan pejantan diwariskan pada keturunan Peranakan Ongole mengikuti pewarisan jenis Mendel. Pewarisan sifat jenis Mendel melalui teknik IB ini tidak berada dalam keseimbangan genetik untuk frekuensi genotipe Mspl dalam kelompok G0 dan G1. Program pemuliaan dengan menggunakan variasi genotipe pejantan dan induk (G0) untuk mewariskan genotipe restriksi enzim Mspl HP melalui teknik IB bisa dipertahankan untuk meningkatkan tingkat sebaran alel yang bervariasi guna meningkatkan keseimbangan genetik dan pemuliaan genotipe pada populasi sapi peranakan Ongole.
\end{abstract}

Kata Kunci: frekuensi genotipe, Mspl HP, sapi peranakan Ongole, pewarisan Mendel

\begin{abstract}
The objectives of this study were to detect the Mendelian mode inheritance of growth hormone $(\mathrm{GH})$ and to establish genotype frequency of GH gene in Ongole-crossbred cattle mated by the artificial insemination (AI) technique. Total of 76 blood samples were collected from Ongole-crossbred cows and bulls (G0), and their progenies (G1) at the Tumaratas AI service center in North Sulawesi province, Indonesia. All blood samples were screened for the presence of GH locus using a PCR-RFLP method involving restricted enzyme $M s p l$ on $1.2 \%$ of agarose gel. Data were analyzed using statistical program function in Excel XP. The results showed that GH locus using alleles of Mspl+ and Mspl-enzyme restriction in Ongole-crossbred cows and bulls was inherited to their Ongole-crossbred progenies following the Mendelian mode inheritance. This Mendelian inheritance generated by AI technique was not under genetic equilibrium for the Mspl genotype frequencies in groups of G0 and G1. The breeding program using genotypes of bulls and cows (G0) for generating the genotype of GH Mspl enzyme restriction by AI technique should be maintained to increase these various allele dispersion rates for breeding under genetic equilibrium of the Ongole-crossbred cattle population.
\end{abstract}

Keywords: genotype frequency, GH Mspl, Mendelian inheritance, Ongole-crossbred cattle

\section{INTRODUCTION}

Growth hormone $(\mathrm{GH})$ is an anabolic hormone synthesized and secreted by the somatotroph cells of the anterior lobe of the pituitary in a circadian and pulsatile manner, the 
pattern of which plays an important role in postnatal longitudinal growth and development, tissue growth, lactation, reproduction, as well as protein, lipid and carbohydrate metabolism (Ayuk and Sheppard, 2006). GH gene with its functional and positional potential has been widely used for marker in several livestock species including the Indonesia local cattle (Jakaria et al., 2009; Sutarno, 2010).

Ongole-crossbred cattle give a significant contribution to Indonesian national meat supplies to fulfill animal protein needs of people. However, the increase of cattle population is not balanced with the national needs of meat consumption due to higher increase of human population. If this condition is uncontrolled, it will lead to the loss of germplasms which is one of the national assets in the animal husbandry field. Negative selections by the breeders and a lack of observation for the crossbreeding of local cattle cause the rest of local cattle to be the inferior cattle with a low quality, will be used to serve as the parental animals in breeding program. If this conventional breeding happens continuously, it will lose the benefit due to the extinction of superior animal germplasms (Hardjosubroto, 2002).

In the wide spread use of artificial insemination (AI) techniques in cattle reproduction industry, the Ongole bulls are used widely as sperm source in crossbreeding program to improve the performance of indigenous local breeds of the cattle in North Sulawesi province. As part of the marker assisted selection (MAS) program which aimed to improve genetic traits in bulls of the Ongole-crossebred cattle, polymerase chain reaction-restriction fragment length polymorphism (PCR-RFLP) has been identified at GH locus with Mspl enzyme restriction. The uncontrol breeding of selected different genotypes of parental bull and cows by the AI technique could be the factor causing genetic inequilibrium of genotype frequency in animal population as a part of non random mating system (Van Vleck et al., 1987). The study of the Mendelian mode inheritance of GH Mspl enzyme restriction has not been widely explored in cattle.

The objectives of this study were to detect the Mendelian mode inheritance and to establish genotype frequency of growth hormone $(\mathrm{GH})$ Mspl enzyme restriction in Ongole-crossbred cattle mated by the artificial insemination (AI) technique in North Sulawesi, Indonesia.

\section{MATERIALS AND METHODS}

\section{Animals and Sample Collection}

This study was carried out in North Sulawesi Province of Indonesia. The total of 74 female animals (parental cows and their progenies) were used and comprised of 37 cows (age ranging 4 to 5 years old), and their 37 female progenies of Ongole crossbred cattle (age ranging 35 to 56 days old). All cows were reared under private areas belong to farmers with unknown ancestors. Progenies were born from those cows mated by artificial insemination using germ plasms (semen) of the two Ongole bulls called "Krista" and "Tunggul" from the artificial insemination bull germ plasm center or Balai Besar Inseminasi Buatan (BBIB) in Singosari, East Java province, Indonesia.

\section{DNA Extraction}

The genotyping process was conducted at the Biotechnology Laboratory Department of Biological Science, Faculty of Mathematics and Natural Science, Sam Ratulangi University, Manado. Blood samples of the cows, their progenies and two Ongole bulls as source of germ plasms were collected from their Jugular vein in $10 \mathrm{ml}$ EDTA (10\%) tubes during July 2011 and stored in the refrigerator $\left(4^{\circ} \mathrm{C}\right)$ until ready for DNA isolation. Genomic DNA from their whole blood were purified by standard protocol using proteinase $\mathrm{K}$ digestion as described by DNA extraction kit (AxyPrep Blood Genomic DNA Miniprep kit, AXYGEN Biosciences, Union city, CA, 94587, USA).

\section{Genotyping for GH and Allele Identification}

Following the genomic DNA isolation, the animals were genotyped for GH locus using PCRRFLP and $1.2 \%$ agarose gel electrophoresis (Sulandari and Zein, 2003). Amplification of the fragment of $327 \mathrm{bp}$ at intron 3 (Gordon et al., 1983) was done with PCR using forward primer 5'-CCCACGGGCAAGAATGAGGC-3'; reverse primer 5'-TGAGGAACTGCAGGGGCCCA-3' (Mitra et al., 1995). The reaction mixture of PCR was performed by using $1 \mathrm{x}$ Taq pol $25 \mu 1$ of master mix (Axygen Biosciences, CA, USA).

To digest this fragment, a protocol of RFLP with restriction enzyme Mspl was used to recognize the particular site of $\mathrm{C} \downarrow$ CGG. The PCR product of $\mathrm{GH}$ gene was digested at $37^{\circ} \mathrm{C}$ for 3 hours by Mspl enzyme. Reaction consisted of 2 
$\mu 1$ Buffer V2 10X, $7.5 \mu \mathrm{L} \mathrm{H}_{2} \mathrm{O}, 0.5 \mu \mathrm{L}$ Enzim Mspl $(20 \mathrm{U} / \mu \mathrm{L})$, and $10 \mu 1 \mathrm{PCR}$ product. PCR protocols to amplify the fragment were done by the initial denaturation temperature step at $94{ }^{\circ} \mathrm{C}$ for $5 \mathrm{~min}$ for 1 cycle followed by 35 cycles of denaturation at $94^{\circ} \mathrm{C}$ for $30 \mathrm{sec}$, annealing at $60^{\circ} \mathrm{C}$ for $30 \mathrm{sec}$, elongation at $72^{\circ} \mathrm{C}$ for $30 \mathrm{sec}$ and a final extention at $72{ }^{\circ} \mathrm{C}$ for 1 minute (Dybus, 2002). Following the end of PCR and RFLP process, the products were then subsequently electrophorated using $1.2 \%$ agarose gel to identify polymorphism of allele based on the length of the band (Figure 1).

\section{Data Analysis}

PCR-RFLP data were used in establishing the observed homozygous Mspl+/+ genotype, heterozygous $M s p 1+/$ - genotype and homozygous Msp1-/- genotype. The Mendelian mode inheritance test of the observed homozygous Mspl+/+ genotypic, heterozygous Mspl+/genotypic and homozygous Msp1-/- genotypic distributions including the genetic equilibrium test of the observed Mspl genotype frequency in animal population was calculated using Chisquare test (Byrkit, 1987) as follows:

$$
\mathrm{X}^{2}=\sum \frac{\left(\mathrm{f}_{\mathrm{o}}-\mathrm{f}_{\mathrm{e}}\right)^{2}}{\mathrm{f}_{\mathrm{e}}}=\sum \frac{\mathrm{f}_{\mathrm{o}}^{2}}{\mathrm{f}_{\mathrm{e}}}-\mathrm{N}
$$

Where

$\mathrm{X}^{2}=$ is the Chi-square distribution,

$f_{o}$ the observed frequency of the $i j k^{\text {th }}$ cell, and

$\mathrm{f}_{\mathrm{e}}$ is the expected frequency of the $\mathrm{ijk}^{\text {th }}$ cell.

$\mathrm{f}_{\mathrm{e}-\mathrm{ijk}} \mathrm{cell}=\frac{\sum \mathrm{f}_{\mathrm{e}-\mathrm{i}} \mathrm{x} \sum \mathrm{f}_{\mathrm{e}-\mathrm{j}}}{\sum \mathrm{f}_{\mathrm{e}-\mathrm{j} \mathrm{jk}}}$

$\sum \mathrm{f}_{\mathrm{e}-\mathrm{i}}$ is the total of observed frequency of the $\mathrm{i}^{\text {th }}$ row; $\sum \mathrm{f}_{\mathrm{e}-\mathrm{j}}$ is the total of observed frequency of the $\mathrm{j}^{\text {th }}$ column; and $\sum \mathrm{f}_{\mathrm{e}-\mathrm{jik}}$ is the total of observed frequency of the $\mathrm{ijk}^{\mathrm{th}}$ cell.

Data were analyzed using software of the statistical program function in Excel XP (2007).

\section{RESULTS AND DISCUSSION}

\section{Polymorphism Detection}

The Mspl digestion of the PCR products produced the fragments of $104 \mathrm{bp}$ and $223 \mathrm{bp}$ for allele Mspl+ and of $327 \mathrm{bp}$ for allele Mspl(Figure 1). These alleles were the same as research reported by Zhou et al. (2005) using
Mspl enzyme restriction in Beijing Holstein and Maylinda (2011) using Mspl enzyme restriction in Grati dairy cows. This enzyme recognized only the restriction site of four nucleotides for $\mathrm{C} \downarrow \mathrm{CGG}$ (Figure 2). Genotype Mspl+/+ consisted of two bands (104 bp, $223 \mathrm{bp}$ ), genotype Msp1+/consisted of three bands (104 bp, $223 \mathrm{bp}, 327 \mathrm{bp}$ ), genotype Msp1-/- consisted of one band (327 bp). The difference of these two fragments of Mspl+ and Mspl-alleles was caused by mutation of Cytosine (C) to Thymine (T) (Rifa 'i, 2010). Gene variation of $\mathrm{GH}$ locus for Mspl in cattle was detected in the position of intron 3 (Rifa'i, 2010) at the sequence position of 1547 based on nucleotide sequence from GenBank, number: M57764.1 (http://www.ncbi.nlm.nih.gov) sourced in Gordon et al. (1983) accessed on March 26, 2011. Mutation occurred on DNA level due to nucleotide changes, either transition or insertion (Cambell and Reece, 2008). Based on the difference of nucleotide restriction sites of each allele, the mutation of Cytosine (C) into Thymine (T) occurred due to nucleotide transition (Figure 2). The transition of $\mathrm{C}$ into $\mathrm{T}$ changed the restriction site of Mspl enzyme (Rifa'i, 2010).

\section{Mendelian Mode Inheritance}

In this study, matings of the 14 homozygous genotyped parental cows of Mspl-/- with homozygous genotyped bull of $\mathrm{Tu}_{-}-/$- produced the all 14 homozygous genotyped progenies of Msp1-/-. In addition, matings of the 4 homozygous genotyped parental cows of Mspl-/with homozygous genotyped bull of $\mathrm{Kr}_{-}+/+$ produced the all 4 heterozygous genotyped progenies of Mspl+/- (Table 1). The same patterns were also observed that matings of the 3 homozygous genotyped parental cows of $\mathrm{Mspl+l}$ + with homozygous genotyped bull of $\mathrm{Kr}_{-}+/+$ produced the all 3 homozygous genotyped progenies of $M s p 1+/+$. In the same observation, matings of the 2 homozygous genotyped parental cows of Mspl+/+ with homozygous genotyped bull of $\mathrm{Tu}_{-}-/-$produced the all 2 heterozygous genotyped progenies of $M s p 1+/-$ (Table 1).

Theorically, the basic Mendelian mode inheritance of the crossing between all the same homozygous genotyped individuals produced all the same homozygous genotyped progenies, while the crossing between recessive homozygous genotyped individuals and dominant homozygous genotyped individuals produced all heterozygous genotyped progenies (Van Vleck, 1987). Based on the Chi square test (Table 1), it was found that the 

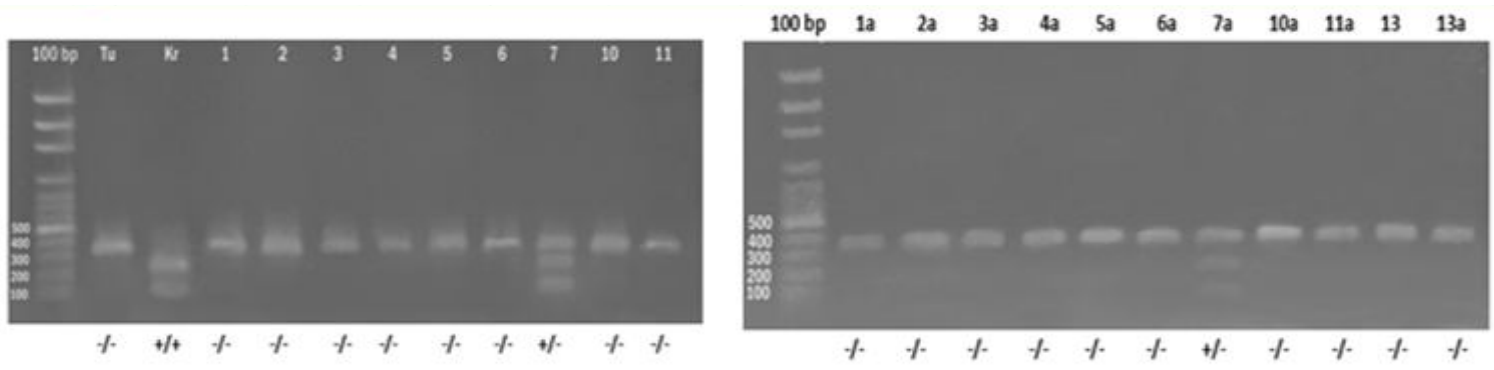

$\mathrm{Tu}=$ Tunggul (Ongole bull), source of sperms for Artificial Insemination (AI)

$\mathrm{Kr}=$ Krista (Ongole bulI), source of sperms for Artificial Insemination (AI)

$1,2,3,4,5,6,7,10,11,13=$ Cows mated by Al method using sperms of Tu

1a, 2a, 3a, 4a, 5a, 6a, 7a, 10a, 11a, 13a = Progenies of Cows mated by Al method using sperms of Tu

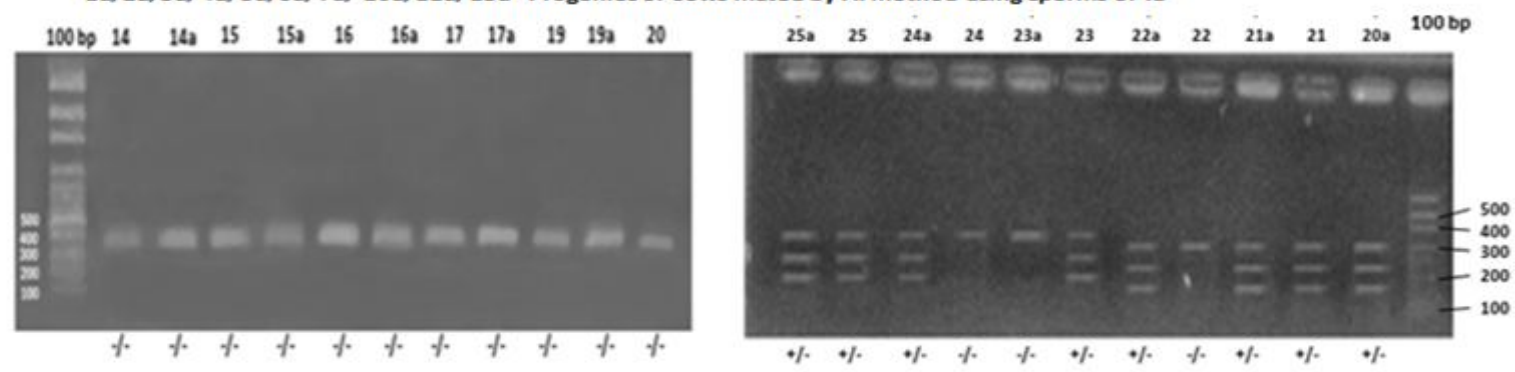

$14,15,16,17,19,21,23,25$ = Cows mated by Al method using sperms of Tu

$14 \mathrm{a}, 15 \mathrm{a}, 16 \mathrm{a}, 17 \mathrm{a}, 19 \mathrm{a}, 21 \mathrm{a}, 23 \mathrm{a}, 25 \mathrm{a}=$ Progenies of Cows mated by Al method using sperms of Tu

$20,22,24$ = Cows mated by Al method using sperms of $\mathrm{Kr}$

$20 \mathrm{a}, 22 \mathrm{a}, 24 \mathrm{a}=$ Progenies of cows mated by Al method using sperms of $\mathrm{Kr}$

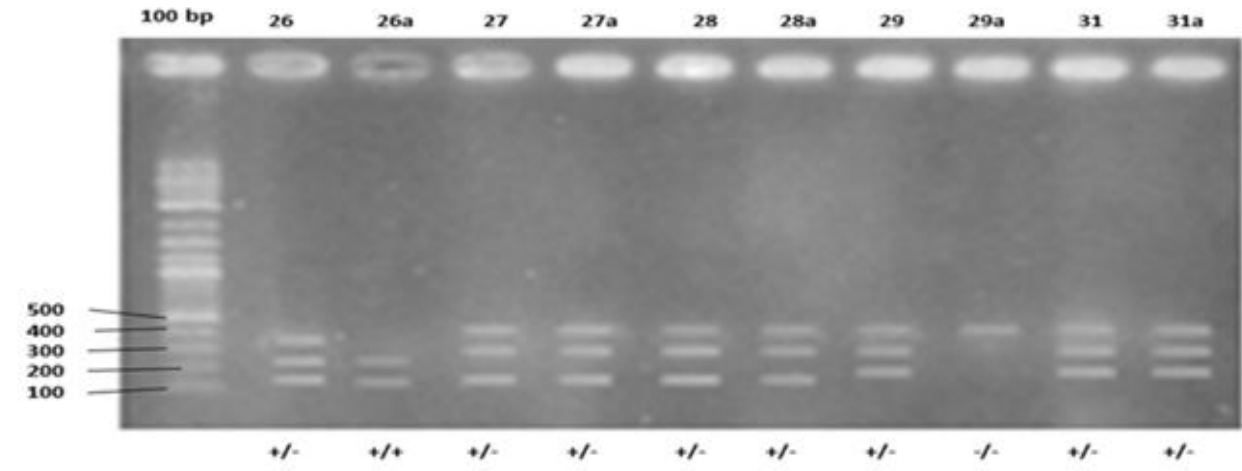

$29=$ Cow mated by AI method using sperms of Tu; $29 a=$ Progeny of cow mated by AI method using sperms of Tu $26,27,28,31$ = Cows mated by Al method using sperms of $\mathrm{Kr}$,

$26 \mathrm{a}, 27 \mathrm{a}, 28 \mathrm{a}, 31 \mathrm{a}=$ Progenies of cows mated by Al method using sperms of $\mathrm{Kr}$.
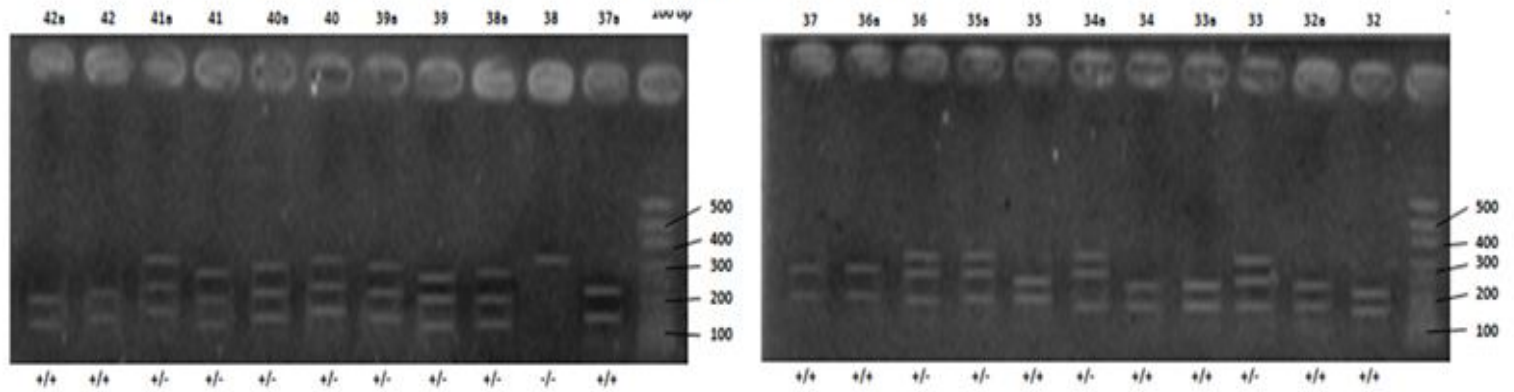

34, 35 = Cows mated by AI method using sperms of Tu; 34a, 35a = Progenies of cows mated by Al method using sperms of Tu $32,33,36,37,38,39,40,41,42$ = Cows mated by $\mathrm{Al}$ method using sperms of $\mathrm{Kr}$

$32 \mathrm{a}, 33 \mathrm{a}, 36 \mathrm{a}, 37 \mathrm{a}, 38 \mathrm{a}, 39 \mathrm{a}, 40 \mathrm{a}, 41 \mathrm{a}, 42 \mathrm{a}=$ Progenies of cows mated by Al method using sperms of $\mathrm{Kr}$

PCR-RFLP, Msp1 Enzyme Restriction

Figure 1. Genotyping Results of Mspl Enzyme Restriction in GH Locus Detected by Agarose Gel Electrophoresis 


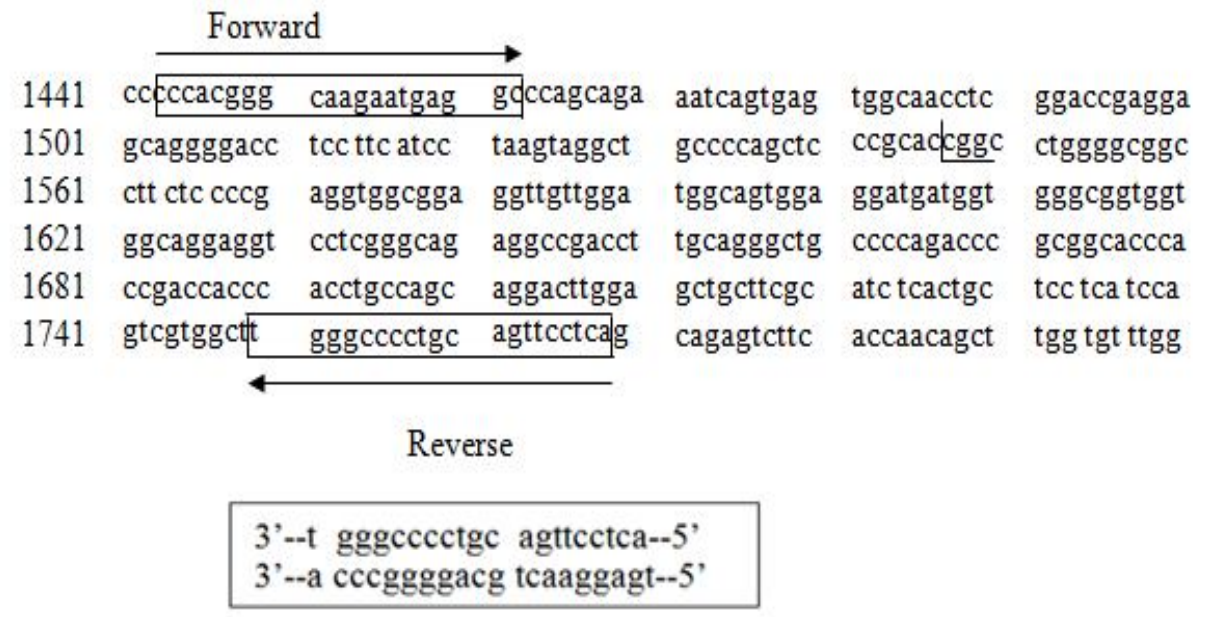

\begin{tabular}{|ll|}
\hline Allele $M s p 1+:$ & 5'---gcccagctcccgcad cggc---3' \\
Allele Msp1- : & 5'---gccccagctcccgcactggc----3' \\
\hline
\end{tabular}

Allele Msp1+ had nucleotide of C on the nucleotide position of 1547

Allele Msp1 - had nucleotide of T on the nucleotide position of 1547

Figure 2. Fragment difference of GH gene and restriction site of Mspl enzyme based on GH gene sequence in cattle accessed from GenBank, number: M57764.1 (http://www.ncbi.nlm.nih.gov).

Table 1. Distribution of Parental and Progeny Genotypes of Msp1+/+ and Mspl-/- Enzyme Restriction at Growth Hormone (GH) Locus in Ongole crossbred cattle in North Sulawesi Based on Genotyping Results Detected by Agarose Gel Electrophoresis

\begin{tabular}{|c|c|c|c|c|c|c|c|c|c|}
\hline \multirow{3}{*}{$\begin{array}{c}\text { Parental } \\
\text { Cow } \\
\text { Genotype }\end{array}$} & \multirow{3}{*}{$\mathrm{n}$} & \multirow{3}{*}{$\begin{array}{l}\text { Parental Bull } \\
\text { Genotype used in } \\
\text { the AI technique }\end{array}$} & \multicolumn{6}{|c|}{ Genotype of Progeny (F1) } & \multirow{3}{*}{ Total } \\
\hline & & & \multicolumn{2}{|c|}{$-/-$} & \multicolumn{2}{|c|}{$+/-$} & \multicolumn{2}{|c|}{$+/+$} & \\
\hline & & & Obs & Exp & Obs & Exp & Obs & Exp & \\
\hline \multirow[t]{3}{*}{ Msp1-/- } & 14 & $\mathrm{Tu}_{-} M s p 1-/-$ & 14 & 14 & 0 & 0 & 0 & 0 & \\
\hline & 4 & $\mathrm{Kr}_{-} M s p 1+/+$ & 0 & 0 & 4 & 4 & 0 & 0 & \\
\hline & & Sub total & $14^{\mathrm{NS}}$ & 14 & $4^{\mathrm{NS}}$ & 4 & $0^{\mathrm{NS}}$ & 0 & $18^{\mathrm{NS}}$ \\
\hline \multirow[t]{3}{*}{ Mspl+/- } & 5 & Tu_Msp1-/- & 2 & 3 & 3 & 2 & 0 & 0 & \\
\hline & 9 & $\mathrm{Kr}_{-} M s p 1+/+$ & 0 & 0 & 6 & 5 & 3 & 4 & \\
\hline & & Sub total & $2^{\mathrm{NS}}$ & 3 & $9^{\mathrm{NS}}$ & 7 & $3^{\mathrm{NS}}$ & 4 & $14^{\mathrm{NS}}$ \\
\hline \multirow[t]{4}{*}{$M s p 1+/+$} & 2 & $\mathrm{Tu}_{-} M s p 1-/-$ & 0 & 0 & 2 & 2 & 0 & 0 & \\
\hline & 3 & $\mathrm{Kr}_{-} M s p 1+/+$ & 0 & 0 & 0 & 0 & 3 & 3 & \\
\hline & & Sub total & $0^{\mathrm{NS}}$ & 0 & $2^{\mathrm{NS}}$ & 2 & $3^{\mathrm{NS}}$ & 3 & $5^{\mathrm{NS}}$ \\
\hline & & Total & $16^{\mathrm{NS}}$ & 17 & $15^{\mathrm{NS}}$ & 13 & $6^{\mathrm{NS}}$ & 7 & $37^{\mathrm{NS}}$ \\
\hline
\end{tabular}

$\mathrm{n}=$ number of parental cows mated by bull using the artificial insemination (AI) technique.

$\mathrm{Tu}=$ Tunggul (name of Ongole bull), $\mathrm{Kr}=$ Krista (name of Ongole bull).

Obs $=$ Observed; Exp $=$ Expected.

NS) $\mathrm{X}^{2}=1.15<\mathrm{X}_{0.05}^{2}\{2\}=5.991$; the values denoting progeny genotypic distributions were under Mendelian mode inheritance $(\mathrm{P}<0.05)$ based on the Chi square test. 
Table 2. Genotype Frequencies of $\mathrm{Mspl}^{+/+}$and $\mathrm{Mspl}^{-{ }_{-}}$at GH Locus in Ongole Crossbred Cows (G0) and Their Progenies (G1)

\begin{tabular}{|c|c|c|c|c|c|c|c|c|c|c|}
\hline \multirow[t]{2}{*}{$\begin{array}{l}\text { Mspl Genotype } \\
\text { of Bull (G0) }\end{array}$} & \multirow[t]{2}{*}{$\mathrm{n}$} & \multirow[t]{2}{*}{$\begin{array}{l}\text { Obs and } \\
\text { Exp Data }\end{array}$} & \multicolumn{3}{|c|}{$\begin{array}{c}\text { Mspl Genotype } \\
\text { Frequency of Parental } \\
\text { Cows (G0) }\end{array}$} & \multirow[t]{2}{*}{$X^{2}$} & \multicolumn{3}{|c|}{$\begin{array}{l}\text { Mspl Genotype } \\
\text { Frequency of Progenies } \\
\text { (G1) }\end{array}$} & \multirow[t]{2}{*}{$X^{2}$} \\
\hline & & & $+/+$ & $+/-$ & $-/-$ & & $+/+$ & $+/-$ & $-/-$ & \\
\hline \multirow[t]{2}{*}{$\operatorname{Krista}\left(\mathrm{Kr}^{+/+}\right)$} & 16 & Obs & 3 & 9 & 4 & $7.09^{*}$ & 6 & 10 & 0 & $22.01^{*}$ \\
\hline & & Exp & 2 & 6 & 8 & & 3 & 7 & 6 & \\
\hline \multirow[t]{2}{*}{ Tunggul $\left(\mathrm{Tu}^{-/-}\right)$} & 21 & Obs & 2 & 5 & 14 & & 0 & 5 & 16 & \\
\hline & & Exp & 3 & 8 & 10 & & 3 & 8 & 10 & \\
\hline
\end{tabular}

Obs $=$ Observed; Exp $=$ Expected.

$\mathrm{n}=$ the number of parental cows mated by the artificial insemination technique

$\left.{ }^{*}\right) \mathrm{X}^{2}=7.09$ and $22.01>\mathrm{X}_{0.05}^{2}\{2\}=5.991$; the values denote that genotype frequencies of the parental cows and their progeny populations were not in genetic equilibrium $(\mathrm{P}>0.05)$ based on the Chi square test.

progeny genotypic distributions were under the Mendelian mode inheritance as denoted by the value of $X^{2}=1.15<X_{0.05}^{2}\{2\}=5.991$.

\section{The Msp1 Genotype Frequencies of Animal Population Using AI Technique}

The frequencies of cow (G0) and progeny (G1) genotypes determined in the population mated by each genotype of bull (G0) were presented in Table 2. Based on the Chi Square test (Table 2), it was found that genotype and allele frequencies of GH Mspl were not under genetic equilibrium $(\mathrm{P}>0.05)$. Maylinda (2011) reported that Grati dairy cow population was in genetic equilibrium. This was supported by the fact that a population property of gene pool for GH-Mspl under the Hardy-Weinberg equilibrium pattern was a function of both allele frequencies and biological interactions among genes (Carter et al., 2005). This inequilibrium of genotypic frequencies of GH Mspl caused the instability of genotypic frequencies of $\mathrm{GH}$ gene from $\mathrm{G} 0$ generation to the next generation (G1) due to the breeding of selected genotypic bulls and parental cows without random mating system in animal population (Cambell and Reece, 2008; Rifa'i, 2010). The factor affecting genetic equilibrium was selection program with non random mating system, such as the artificial insemination mating system (Van Vleck et al., 1987).

Jawasreh et al. (2012) reported that breeding program must be continued as the first step to increase the frequency of the favorable allele in breeding station. In North Sulawesi province, the artificial insemination service center applied the straw containing spermatozoa germplasm of Ongole bull called "Krista" and "Tunggul" from germplasm center (Balai Besar Inseminasi Buatan) Singosari, East Java province. Carter et al. (2005) reported the analysis of gene interaction and found that it might be two or more genes can interact to express a particular phenotype.

\section{CONCLUSION}

The selected growth hormone locus using alleles of $M s p 1+$ and $M s p 1$ - enzyme restriction in Ongole-crossbred parental cows and bulls was inherited to their progenies following Mendelian mode inheritance. This Mendelian inheritance generated by AI technique was not under genetic equilibrium for $M s p l$ genotype frequencies in groups of parental animals (G0) and their progenies (G1). The breeding program using genotypes of bulls and cows (G0) for generating the genotype of GH Mspl enzyme restriction by AI technique should be maintained to increase these various allele dispersion rates for breeding under genetic equilibrium of the Ongole- 
crossbred cattle population.

\section{ACKNOWLEDGMENT}

The financial support of the Ministry of Education and Culture, Republic of Indonesia through their Research under Doctorate Scholarship Program is gratefully acknowledged. The authors also acknowledge J. Kuhu and his farmer group members at Tumaratas village, district of West Langowan, under development of the artificial insemination service center of Minahasa regency, North Sulawesi province for their assistance in animal data collection.

\section{REFERENCES}

Ayuk, J. and M.C. Sheppard. 2006. Growth hormone and its disorder. Postgrad. Med. J. 82(963):24-30

Byrkit, D.R. 1987. Statistics Today: A Comprehensive Introduction. The Benjamin/Cummings Publishing Company, Inc. 2727 Sand Hill Road Menlo Park, California, USA.

Cambell, N.A. and J.B. Reece. 2008. Biology. Eighth Edition. Pearson Education Inc., California.

Carter, A.J.R., J. Hermisson and T.F. Hansen. 2005. The role of epistatic gene interactions in the response to selection and the evolution of evolvability. Theor. Popul. Biol. 68:179196

Dybus, A. 2002. Associations between Leu/Val polymorphism of growth hormone gene and milk production traits in Black-and-white cattle. Archives Anim. Breeding. 45(5):421428

Gordon, D.F., D.P. Quick, C.R. Ewin, J.E. Donelson and R.R. Maurer. 1983. Nucleotide sequences of the bovine growth hormone chromosomal gene. GenBank, number: M57764.1 (http://www.ncbi.nlm.nih.gov) accessed on March 26, 2011

Hardjosubroto, W. 2002. Arah dan sasaran penelitian dan pengembangan sapi potong di
Indonesia: Tinjauan dari segi pemuliaan ternak. Workshop sapi potong, Malang, 1112 April 2002.

Jakaria, R.R. Noor, H. Martojo, D. Duryadi and B. Tappa. 2009. Identification of growth hormone (Gh) gene MspI and AluI loci polymorphism in beef cattle. Faculty of Animal Science, Bogor Agricultural University. Proceedings, the $1^{\text {st }}$ International Seminar on Animal Industry 2009. p.42-47.

Jawasreh, K.I.Z., H. Ababneh, F.T. Awawdeh, M.A. AL-Massad and A.M. Al-Majali. 2012. Genotype and allelic frequencies of a newly identified mutation causing blindness in Jordanian Awassi sheep flocks. Asian-Aust. J. Anim. Sci. 25(1):33-36.

Maylinda, S. 2011. Genetic polymorphism of growth hormone locus and its association with body weight in Grati dairy cows. International J. Biotechnology and Moleculer Biology Research. 2 (7):117-120

Mitra, A., P. Sciilee, C.R. Balakrisiinan and F. Pirciiner. 1995. Polymorphisms at growth hormone and prolactine loci in Indian cattle and buffalo. J. Anim. Breed. and Genet. 12:71-74

Rifa'i, M. 2010. Genetika Rekombinasi dan Populasi. Edisi Pertama. Penerbit Galaxy Science, Malang, 65145

Sulandari, S. and M.S.A. Zein. 2003. Protocols in DNA Laboratory, Center of Biology Research, The Indonesian Institute of Sciences, Bogor. Pp.23-45

Sutarno. 2010. Genetic variation among Indonesian native cattle breeds based on polymorphisms analysis in the growth hormone loci and mitochondrial DNA. Biodiversitas 11:1-5

Van Vleck, L.D., E.J. Pollak and E.A.B. Oltnacu. 1987. Genetics for the Animal Science. W.H. Freeman and Company, New York.

Zhou, G.L., H. Liu, C. Liu, S.L. Guo, Q. Zhu and Y.H. Wu. 2005. Association of genetic polymorphism in GH gene with milk production traits in Beijing Holstein cows. J. Biosci. 30(5):595-598 